\title{
Effects of the Soil Incorporation of Increasing Amounts of Non-Fermented Wet Pomace on the Oil Yield and Acid Profile of Sunflower Seeds
}

\author{
Giovanna Cucci*1, Taddeo Rotunno², Giovanni Lacolla ${ }^{1}$, Roberto Di Caterina ${ }^{2}$ \\ ${ }^{1}$ Dipartimento di Scienze delle Produzioni Vegetali, Università di Bari \\ Via Amendola 165/A, 70125 Bari, Italy \\ ${ }^{2}$ Dipartimento di Scienze Agroambientali, Chimica e Difesa Vegetale, Università di Foggia \\ Via Napoli 25, 71100 Foggia, Italy
}

Received: 12 March 2007. Accepted: 10 October 2007.

\begin{abstract}
The agricultural use of olive processing waste is a strategic resource in the integrated management of the agricultural system as it satisfies the two objectives of evacuating the olive-processing residue and using it beneficially for agricultural purposes. For such aims, a research was conducted in Bari (South of Italy) to study the effects of the incorporation into the soil of increasing amounts of non-fermented wet pomace (WP) $(0,17.5,35,70,105,140,175$, $210 \mathrm{Mg} \mathrm{ha}^{-1}$ ) on the oil yield and acid profile of sunflower seeds.

The results obtained point out that the seed yield was negatively affected by the application of WP starting from 70 $\mathrm{Mg} \mathrm{ha}^{-1}$; an opposite trend was observed for the seed oil yield. The incorporation of WP has also affected the oil fatty acids' composition. Oleic and linoleic acids, the principal fatty acids (beyond $90 \%$ of total fatty acids), showed significant variations: from the control treatment to the one receiving the maximum application of waste, oleic acid decreased $(-5.4 \%)$, linoleic acid increased $(+6.6 \%)$, and the saturated fatty acids fraction decreased $(-7.6 \%)$.
\end{abstract}

Key-words: acid profile; oil yield; sunflower; wet pomace.

\section{Introduction}

The agricultural use of agro-industrial waste is a strategic resource in the integrated management of the agricultural system as it meets the twofold objectives of evacuating olive-processing waste and using it beneficially for agricultural purposes (Ceccon, 2001).

The disposal of olive waste is a common problem to all the Mediterranean countries (Bonari et al., 2001), which is still related to vegetable water (Paris, 1998; Ceccon, 2001) and has been studied for a long time (Andrich et al., 1986; Proietti et al., 1988; Balice et al., 1990; Bonari and Ceccarini, 1991; Saviozzi et al., 1991; Wlassics et al., 1992; Bonari and Ceccarini, 1993; Amirante, 1996). However, currently it is being substituted by the disposal of Wet Pomace (WP) (Casa et al. 2001), as the regulations in force
(D.L. n. 99 of 27.01.92, L. 574/96) classify it as a conditioner and allow its controlled spreading onto the soil.

The agricultural use of wet pomace is allowed in three possible alternative ways:

- The application of $210 \mathrm{Mg} \mathrm{ha}^{-1}$ of waste once every 3 years;

- The application of $2 / 3$ of the maximum amount $\left(140 \mathrm{Mg} \mathrm{ha}^{-1}\right)$ in the first year, and $1 / 3\left(70 \mathrm{Mg} \mathrm{ha}^{-1}\right)$ in the second year;

- The application of $1 / 3$ of the maximum amount allowed every year.

In Italy, where the soil organic matter content is low while the Mediterranean climatic conditions contribute to its fast mineralization, incorporating of Wet Pomace WP on the agricultural soils could increase their fertility (Papini et al., 2000).

Nevertheless, like all vegetable water, WP

\footnotetext{
* Corresponding Author: Tel.: +39 80 5443005; Fax: +39 80 5442976. E-mail address: giovanna.cucci@agr.uniba.it
} 
has some negative impacts when used in agriculture; they are related mainly to the difficulty of fully incorporating it into the soil, and for its toxic effects on plants due to the presence of high amounts of polyphenols (Rice, 1979; Lynch, 1980; Marambe and Ando, 1992) which have, however, a quick decay (Riffaldi et al., 1990; Comacho et al., 2000). Moreover, the oil residues in WP reduce the activity of the soil microflora and its multiplication (Olivier, 1993). During the WP spreading, the applied material might encounter severe difficulties to be bound with the soil particles, and some toxic effects might appear on the crops, especially during the emergence phase, when higher amounts of WP (105-140-210 Mg ha-1) are applied. In fact, Bonari and Ceccarini (2000) observed that, during the germination, young sunflower plants in direct contact with WP particles showed a reduced and a slower growth with respect to plants grown in the untreated soil or when a low amount of WP (up to $70 \mathrm{Mg} \mathrm{ha}^{-1}$ ) was added. Besides, based on the evaluation of yield parameters (total biomass produced, calathide weight, yield and unit mean weight of seeds) they found statistically significant differences in relation to different rates of WP tested, with negative results starting from $70 \mathrm{Mg} \mathrm{ha}^{-1}$ of applied waste.

The results of the conducted researches reported in literature usually indicate that the farming practices that promote seed formation and oil yield may result also in a better acid composition of sunflower seed oil (Monotti, 2002). In human nutrition, the nutritional quality of sunflower oil depends on the contents of both monounsatured and polyunsatured fatty acids. From one hand, a diet rich in oleic acid helps to reduce the cholesterol in blood plasma and thus the risk of coronary diseases (Grundy, 1986; Grundy, 1989; Miller et al., 1987; Yodice, 1990; Deplanque, 2000); moreover, a high level of oleic acid ensures a high thermal-oxidative stability during the frying process. From the other hand, linoleic acid is also an important constituent of human diet as it is considered an essential fatty acid; its absence causes neurological disorders (Holman et al., 1988). The oil fatty acids composition depends not only on sunflower genotype (standard and high oleic hybrids) but is also related to the climatic conditions and the cultural practices of oil producing areas In fact, the levels of oleic and linoleic acids in sunflower seed oil could be affected by the nitrogen fertilisation (Pritoni et al., 1999), temperature (Fick 1984; Garcès et al., 1989; Anastasi et al., 2001), sowing time (Pritoni et al., 1999; Anastasi et al., 2000; Flagella et al., 2002), varieties (Monotti et al., 1999; Laureti et al., 2000), water supply (Santonoceto et al., 1999; Baldini et al., 1999-2000; Santonoceto et al., 2003) and salt stress (Francois, 1986; Tedeschi et al., 1997; Flagella et al., 2004; Cucci et al., 2004); yet, researches on the effects of incorporating olive processing waste into the soil are still poor (Cucci et al., 2005). As a consequence, a research was undertaken at the DSPV of Bari University with the aim of evaluating the effect of the soil incorporation of increasing amounts of WP on Sunflower (Helianthus annuus L.).

\section{Materials and methods}

The test was carried out in the experimental field close to the Faculty of Agriculture of Bari University (Italy), within a long-term study aiming at evaluating the effect of the soil incorporation of increasing amounts of wet pomace (WP) on a series of crops (sunflower-wheatwheat), grown in pots $(0.72 \mathrm{~m}$ in size and 0.60 $\mathrm{m}$ deep), located outdoors and filled with a clayloam soil which characteristics are given in Table 1.

The experiment was arranged by randomized blocks with six replicates. Eight increasing levels of WP with $65 \%$ moisture level (0 control, $0.7,1.4,2.9,4.3,5.7,7.2,8.6 \mathrm{~kg} \mathrm{pot}^{-1}$, corresponding respectively to $0,17.5,35,70,105,140$, $175,210 \mathrm{Mg} \mathrm{ha}^{-1}$ ) were applied. Olive pomace was taken from an oil mill and spread onto a ploughed soil during winter.

After spreading, olive waste was immediately ploughed in; and after two months, the soil was refined in order to prepare the seedbed for the cleaning crop. During the soil incorporation of wet pomace, it has been necessary to go several times through the ploughing as mixing it with the soil particles was not easy. Some inconveniences were observed mostly due to the failure in blending the spread waste and the soil, and as result, pomace particles were distinguishable for a long time on the surface of the treated pots. 
Table 1. Main characteristics of the soil.

\begin{tabular}{|c|c|}
\hline \multicolumn{2}{|l|}{ Chemical properties: } \\
\hline Total Nitrogen (Kjeldahl meth.) (\%o) & 1.65 \\
\hline Available phosphorus (Olsen meth.) (ppm) & 52.50 \\
\hline Exchang. potassium (ammonium & \\
\hline acetate meth.) (ppm) & 352.00 \\
\hline Organic matter (Walkley Black meth.) (\%) & 3.13 \\
\hline Total limestone (\%) & 2.58 \\
\hline Active limestone (\%) & 1.40 \\
\hline $\mathrm{pH}\left(\mathrm{pH}\right.$ in $\left.\mathrm{H}_{2} \mathrm{O}\right)$ & 7.18 \\
\hline $\left.\mathrm{ECe}(\mathrm{dS} \mathrm{m})^{-1}\right)$ & 0.78 \\
\hline ESP & 0.80 \\
\hline $\mathrm{CEC}\left(\mathrm{BaCl}_{2}\right.$ meth $)(\mathrm{meq} / 100 \mathrm{~g}$ of dry soil $)$ & 31.61 \\
\hline \multicolumn{2}{|l|}{ Particle-size analysis $(\mathrm{mm})$ : } \\
\hline Total sand $(\%) \quad 2>\varnothing>0.02$ & 20.94 \\
\hline $0.02>\varnothing>0.002$ & 44.00 \\
\hline$\varnothing<0.002$ & 35.06 \\
\hline \multicolumn{2}{|l|}{ Hydrologic properties: } \\
\hline Field capacity (field determ.) (\% d.w.) & 35.80 \\
\hline Wilting point $(-1.5 \mathrm{MPa})(\%$ d.w. $)$ & 18.40 \\
\hline Bulk density $\left(\mathrm{kg} \mathrm{dm}^{-3}\right)$ & 1.20 \\
\hline
\end{tabular}

Sunflower (cv HS 90), a high oleic hybrid, was sown on 29 April 2002, by drilling seeds in two drills per pot $0.4 \mathrm{~m}$ apart. After emergence, seedlings were thinned to two plants per pot. Just after sowing, to facilitate seed germination and plantlet emergence, the crop was irrigated by fresh water so as to re-establish field capacity in the top $0.2 \mathrm{~m}$ layer. From plant emergence to the end of the irrigation season, irrigation was applied whenever $30 \%$ of the maximum available water was lost by evapotranspiration and bringing it back to field capacity. Plants were harvested on September $5^{\text {th }} 2002$ and the following biometric, yield and qualitative parameters were determined: plant height and shoot dry biomass, calathide diameter, number and weight of seeds per calathide, 1000 seeds' weight, oil yield and content of the main fatty acids; the procedure of the fatty acids' analysis is explained in the following paragraph. The data were subject to the statistical analysis as described below and are shown in Tables 2 and 3 and plotted in Figure 1.

\section{Analysis of fatty acids}

The achenes were dried in ventilated oven and then homogenized in a blender (Waring Laboratory Blender, 06055 New Hartford, Connecticut, USA). The oil was extracted from seed meal by using a CEM model MDS 2100 microwave ex- tractor (CEM Corporation, 28106-0200 Matthews, North, Carolina, USA) under the following conditions: the extraction vessels were loaded with about $1 \mathrm{~g}$ of seed meal and $50 \mathrm{~mL}$ of diethyl ether.

The microwave oil extraction method was proved to be as accurate and precise as the traditional one (Soxhlet), and even faster since it required about $40 \mathrm{~min}$ at $105{ }^{\circ} \mathrm{C} v s$ 6-8 hours for the Soxhlet extraction. The recovery data obtained from the two extraction methods were statistically not different when compared by linear regression procedure (the regression equation was $\mathrm{y}=-0.001+1.012 . x, \mathrm{R}^{2}=0.999$, and intercept and slope were not different from 0 and 1 , respectively, at $\mathrm{P}<0.05$ ).

After removal of the meal from the liquid phase by filtration, the oil was recovered by solvent evaporation, and submitted to the methylation treatment using the official method (EEC, 1991).

The fatty acid composition was determined by using a Fisons model GC-8160 gaschromatograph (Italian Fisons, I - 20100 Milan, Italy) equipped with a split-splitless injector, a ZB Wax fused silica column $(30 \mathrm{~m}, 0.53 \mathrm{~mm}$, i.d, 0,50 $\mu \mathrm{m}$ film thickness; Zebron, Phenomenex, Torrance, CA, USA) and a flame ionization detector (FID) connected to a Chromquest signal acquisition and data reporting (Thermoquest, Milan, Italy). The carrier gas was helium at a linear velocity of $250 \mathrm{~mm} / \mathrm{s}$. The operating temperature of injector and FID were respectively

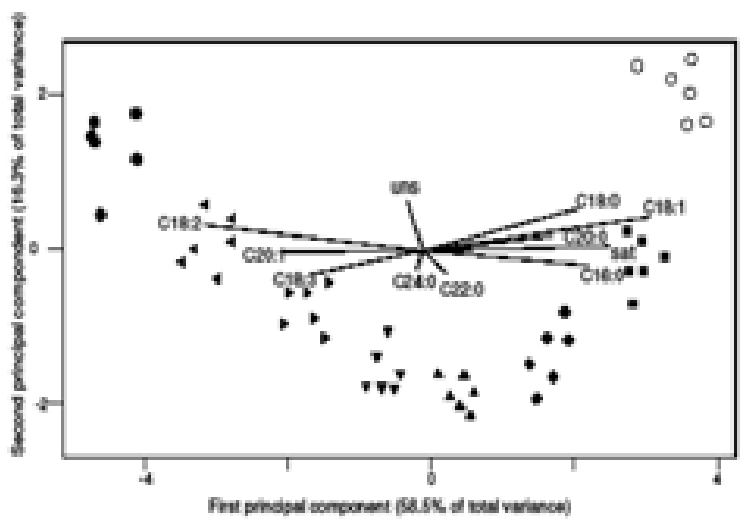

Figure 1. Principal Component Analysis of the fatty acids in the 48 sunflower oil samples subdivided in 8 groups of 6 repetitions, according to the doses of wet olive pomace used in the trial: $17.5(\mathbf{\square}) 35.0(\nabla), 70.0(\mathbf{\Delta}), 105.0(\boldsymbol{\nabla}), 140.0(\nabla) 175.0$ $(\triangleleft), 210.0(\bullet)$ g of wet olive pomace per pot, plus control (o). sat: $\Sigma$ (C18:1,C18:2,C18:3,C20:1); uns: $\Sigma(\mathrm{C} 18: 1, \mathrm{C} 18: 2, \mathrm{C} 18: 3$, C20:1) 
Table 2. Influence of soil incorporation of increasing amounts of non-fermented wet olive pomace on biometric and yield parameters of the sunflower hybrid HS9O. The values are means of six repetitions of sunflower seed oil samples; each analysis was performed in triplicate.

\begin{tabular}{lcccccccc}
\hline Biometric and yield parameters & \multicolumn{7}{c}{ Wet pomace amount $(\mathrm{Mg}$} & ha $\left.^{-1}\right)$ \\
\hline & 0.0 & 17.5 & 35.0 & 70.0 & 105.0 & 140.0 & 175.0 & 210.0 \\
\hline Plant height (cm) & $145 \mathrm{~A}$ & $143 \mathrm{~A}$ & $141 \mathrm{~A}$ & $140 \mathrm{~A}$ & $146 \mathrm{~A}$ & $142 \mathrm{~A}$ & $135 \mathrm{~A}$ & $132 \mathrm{~A}$ \\
Calathide diameter (cm) & $18.2 \mathrm{~A}$ & $18.2 \mathrm{~A}$ & $17.3 \mathrm{~A}$ & $15.7 \mathrm{~B}$ & $15.5 \mathrm{~B}$ & $14.8 \mathrm{BC}$ & $14 \mathrm{BC}$ & $13.6 \mathrm{C}$ \\
Achenes per plant & $1367 \mathrm{~A}$ & $1358 \mathrm{~A}$ & $1299 \mathrm{~A}$ & $1247 \mathrm{~B}$ & $1233 \mathrm{~B}$ & $1224 \mathrm{~B}$ & $1062 \mathrm{C}$ & $1074 \mathrm{C}$ \\
1000 achene weight (g) & $86.6 \mathrm{~A}$ & $82.4 \mathrm{AB}$ & $88.1 \mathrm{~A}$ & $79.5 \mathrm{ABC}$ & $72.6 \mathrm{BC}$ & $70.2 \mathrm{BC}$ & $69.3 \mathrm{BC}$ & $67 \mathrm{C}$ \\
Achene yield per plant (g) & $118.4 \mathrm{~A}$ & $109.6 \mathrm{~A}$ & $111.9 \mathrm{~A}$ & $93.6 \mathrm{~B}$ & $90.5 \mathrm{~B}$ & $85.9 \mathrm{BC}$ & $73.6 \mathrm{C}$ & $72 \mathrm{C}$ \\
Shott dry biomass per plant (g) & $277.0 \mathrm{~A}$ & $249.0 \mathrm{~A}$ & $213.0 \mathrm{AB}$ & $180.0 \mathrm{~B}$ & $179.0 \mathrm{~B}$ & $177.0 \mathrm{~B}$ & $159.0 \mathrm{C}$ & $152.0 \mathrm{C}$ \\
Oil yield (\%) & $47.5 \mathrm{~F}$ & $48.2 \mathrm{EF}$ & $48.9 \mathrm{DE}$ & $49.7 \mathrm{D}$ & $52 \mathrm{C}$ & $53.3 \mathrm{~A}$ & $53 \mathrm{AB}$ & $52.4 \mathrm{BC}$ \\
Oil yield per plant (g) & $52.8 \mathrm{~B}$ & $52.8 \mathrm{~B}$ & $54.7 \mathrm{~A}$ & $46.5 \mathrm{C}$ & $47.1 \mathrm{C}$ & $45.8 \mathrm{C}$ & $39 \mathrm{D}$ & $37.7 \mathrm{E}$ \\
\hline
\end{tabular}

Values in a row followed by the same letter are not significantly different, according to Tukey's test at $\mathrm{P} \leq 0.01$.

$250{ }^{\circ} \mathrm{C}$ and $280{ }^{\circ} \mathrm{C}$. The sample injection $(1 / \mu \mathrm{l})$ mode was split with a ratio of $1: 100$. The oven temperature programme was $165^{\circ} \mathrm{C}$ for a duration of $3 \mathrm{~min}$, raised to $220^{\circ} \mathrm{C}$ by $1.5^{\circ} \mathrm{C} / \mathrm{min}$. A commercial standard mixture (Larodan Fine Chemicals, Malmo, Sweden) of fatty acids methyl esters was used for calibration and for obtaining the correction factors to compensate for the different sensitivity of FID to each fatty acid (Gargano and Toppino, 1981).

\section{Statistical analysis}

The data set consisted in 48 cases (six blocks each of 8 pots where the sunflower plants were grown), 9 biometric and production parameters (Tab. 2), and 9 chemical parameters, i.e. the fatty acids C16:0, C18:0, C18:1, C18:2, C18:3, C20:0, C20:1, C22:0, C24:0. The cases were classified into eight groups of six, according to the seven different doses of WP used in the experiment, plus the control. Principal component analysis

Table 3. Influence of the soil incorporation of increasing amounts of non-fermented wet pomace on the fatty acid profile in the oil of sunflower hybrid HS9O. The values are means of six repetitions of sunflower seed oil samples, each analysis was performed in triplicate

\begin{tabular}{|c|c|c|c|c|c|c|c|c|c|c|}
\hline \multirow[t]{2}{*}{ Fatty acids (\%) } & \multicolumn{8}{|c|}{ Wet pomace amount $\left(\mathrm{Mg} \mathrm{ha}{ }^{-1}\right)$} & \multicolumn{2}{|c|}{ Effect } \\
\hline & 0.0 & 17.5 & 35.0 & 70.0 & 105.0 & 140.0 & 175.0 & 210.0 & S.E. & $\mathrm{P}<$ \\
\hline $\begin{array}{l}\text { Palmitic acid } \\
\text { (C16:0) }\end{array}$ & $5.07 \mathrm{~A}$ & $5.01 \mathrm{AB}$ & $4.98 \mathrm{AB}$ & 4.94BC & $4.85 \mathrm{CD}$ & $4.88 \mathrm{CD}$ & $4.82 \mathrm{DE}$ & $4.75 \mathrm{E}$ & 0.02 & 0.05 \\
\hline $\begin{array}{l}\text { Stearic acid } \\
(\mathrm{C} 18: 0)\end{array}$ & $3.26 \mathrm{~A}$ & $3.24 \mathrm{AB}$ & 3.19ABC & 3.15BCD & $3.13 \mathrm{CD}$ & 3.O6DE & 3.01EF & $2.93 \mathrm{~F}$ & 0.02 & 0.05 \\
\hline $\begin{array}{l}\text { Oleic acid } \\
(\mathrm{C} 18: 1)\end{array}$ & $53.4 \mathrm{~A}$ & $53.1 \mathrm{AB}$ & $52.8 \mathrm{AB}$ & $52.6 \mathrm{~B}$ & $51.9 \mathrm{C}$ & $51.4 \mathrm{CD}$ & $51.2 \mathrm{D}$ & $50.5 \mathrm{E}$ & 0.15 & 0.05 \\
\hline $\begin{array}{l}\text { Linoleic acid } \\
(\mathrm{C} 18: 2)\end{array}$ & $38.0 \mathrm{~F}$ & $38.1 \mathrm{EF}$ & 38.3DE & $38.4 \mathrm{D}$ & $38.7 \mathrm{C}$ & $39.0 \mathrm{~B}$ & $39.2 B$ & $40.5 \mathrm{~A}$ & 0.13 & 0.05 \\
\hline $\begin{array}{l}\text { Linolenic acid } \\
\text { (C18:3) }\end{array}$ & $0.02 \mathrm{~F}$ & $0.05 \mathrm{E}$ & $0.06 \mathrm{D}$ & $0.06 \mathrm{C}$ & $0.07 \mathrm{~B}$ & $0.08 \mathrm{~B}$ & $0.08 \mathrm{~A}$ & $0.10 \mathrm{~A}$ & 0.003 & 0.05 \\
\hline $\begin{array}{l}\text { Arachic acid } \\
(\mathrm{C} 20: 0)\end{array}$ & $0.27 \mathrm{~A}$ & $0.26 \mathrm{AB}$ & $0.26 \mathrm{BC}$ & $0.25 \mathrm{C}$ & $0.24 \mathrm{D}$ & $0.23 \mathrm{DE}$ & $0.22 \mathrm{DE}$ & $0.20 \mathrm{~F}$ & 0.004 & 0.05 \\
\hline $\begin{array}{l}\text { Eicosenoic acid } \\
\text { (C20:1) }\end{array}$ & $0.17 \mathrm{E}$ & $0.17 \mathrm{E}$ & $0.18 \mathrm{D}$ & $0.19 \mathrm{C}$ & $0.19 \mathrm{C}$ & $0.20 \mathrm{BC}$ & $0.20 \mathrm{AB}$ & $0.21 \mathrm{~A}$ & 0.004 & 0.05 \\
\hline $\begin{array}{l}\text { Beehnic acid } \\
(\mathrm{C} 22: 0)\end{array}$ & $0.62 \mathrm{AB}$ & $0.63 \mathrm{~A}$ & $0.63 \mathrm{~A}$ & $0.61 \mathrm{AB}$ & $0.62 \mathrm{AB}$ & $0.62 \mathrm{AB}$ & $0,62 \mathrm{AB}$ & $0.61 \mathrm{AB}$ & 0.003 & n.s. \\
\hline $\begin{array}{l}\text { Lignoceric acid } \\
\text { (C24:0) }\end{array}$ & $0.11 \mathrm{AB}$ & $0.12 \mathrm{AB}$ & $0.12 \mathrm{AB}$ & $0.13 \mathrm{~A}$ & $0.14 \mathrm{~A}$ & $0.14 \mathrm{~A}$ & $0.14 \mathrm{~A}$ & $0.13 \mathrm{~A}$ & 0.002 & n.s. \\
\hline $\begin{array}{l}\Sigma(\text { Saturated } \\
\text { fatty acids })\end{array}$ & $9.33 \mathrm{~A}$ & $9.29 \mathrm{AB}$ & $9.20 \mathrm{BC}$ & $9.11 \mathrm{CD}$ & $9.01 \mathrm{DE}$ & 8.93EF & $8.82 \mathrm{~F}$ & $8.63 \mathrm{G}$ & 0.04 & 0.05 \\
\hline $\begin{array}{l}\Sigma(\text { Unsaturated } \\
\text { fatty acids) }\end{array}$ & $91.5 \mathrm{~A}$ & $91.4 \mathrm{~A}$ & $91.3 \mathrm{~A}$ & $91.3 \mathrm{~A}$ & $90.9 \mathrm{AB}$ & $90.7 \mathrm{AB}$ & $90.7 \mathrm{AB}$ & $91.3 \mathrm{~A}$ & 0.12 & n.s. \\
\hline
\end{tabular}

Values in a row followed by the same letter are not significantly different, according to Tukey's test at $\mathrm{P} \leq 0.05$ n.s: not significant. 
(PCA) was used to explore the influence of the different amounts of WP used on the fatty acids profile of sunflower seed oil. This multivariate method is used for preliminary analysis to acquire a general view of the problem (Massart et al., 1988). The results of PCA can be graphically represented in two dimensional plots (see Fig. 1), showing the relationships among variables (loading plot), among cases (score plot), and between cases and variables.

The data were subjected also to the ANOVA procedure of the M-STAT statistical package (ver. 21, Crop and Soil Science Department, Michigan State University) to test the effects due to the incorporation of olive pomace. Differences between means were compared according to the Tukey's test. Regression analysis (Jump Statistical software by SAS Institute) was performed to validate the microwave oil extraction method with respect to traditional procedure by Soxhlet.

\section{Results and discussion}

The results obtained from this study on the spreading of non-fermented WP on a bare soil prepared for sunflower crop allow for the following conclusions to be drawn: the high moisture and oil contents in the waste caused some difficulties during both spreading and in the subsequent homogenisation with the soil, inducing phytotoxicity in the treatments with high waste application (105-140-175 and $210 \mathrm{Mg} \mathrm{ha}^{-1}$ ) to the seedlings since emergence, which is in agreement with previous works (Paris, 1998; Bonari et al., 2001; Casa et al., 2001).

The seedlings of the treatments receiving high quantities of WP showed a reduced and a slower growth compared to those that had received lower amounts of WP, especially during the very early growing stages (germination-emergence). In addition, throughout the different growth stage, crop diversity was observed as related to the increasing amount of WP, extension of the growth stages and shortening of the reproductive phases, with a faster and earlier embryo development and lipid accumulation was also observed, in agreement with what is reported for this species grown under stress conditions caused by olive waste (Paris, 1998), water deficit (Baldini et al., 2000 and Santonoceto et al., 2003).

The applied treatment has not affected some tested parameters (plant density, plant height) (Tab. 2), whereas others (shoot dry biomass, calathide diameter and weight, seed number per calathide, yield and mean weight of seeds) (Tab. 2) have shown statistically significant differences expressed by a negative trend in a response to an increased quantity of the applied olive waste.

However, for the treatments receiving low quantities of WP (17.5-35.0 Mg ha $\left.\mathrm{M}^{-1}\right)$, shoot dry biomass yield and seed yield with its components were not statistically different from the control (Tab. 2).

Sunflower was negatively affected by the application of WP starting from $70 \mathrm{Mg} \mathrm{ha}^{-1}(21 \%$ reduction in seed yield as compared to the control) but did not show any yield reduction in the range of $105-140 \mathrm{Mg} \mathrm{ha}^{-1}$. Further reductions were observed with the highest rates of application $\left(175-210 \mathrm{Mg} \mathrm{ha}^{-1}\right.$ ) (reduction in seed yield by 38 and $39 \%$ respectively as compared to the control treatment). These differences in yield are mainly attributable to the mean weight of seeds and the calathide size. The control, as compared to the treatments with an application of 70 and $210 \mathrm{Mg} \mathrm{ha}^{-1}$ of WP, has shown a higher mean seed weight (by 26 and $44 \%$ ) and a greater calathide diameter (by 12 and 23\%) (Tab. 2). Francois (1986) attributed the yield reduction of sunflower submitted to salt stress $\left(<10.2 \mathrm{dS} \mathrm{m}^{-1}\right.$ ECe $)$ to the lower number of seeds per calathide due, in turn, to the calathide size, to the number of flowers or aborted seeds per flower, whereas it did not show any substantial difference in the mean weight of seeds. An opposite trend was instead observed for seed oil yield: it increased by $17 \%$ as compared to the control, when $210 \mathrm{Mg} \mathrm{ha}^{-1}$ of WP was applied. When the waste application rate increased, and as a result of the compensation induced by the reduction in seed yield and the increase in oil yield, the highest oil yield per plant $(54.7 \mathrm{~g})$ was found in the crop submitted to an application of $35 \mathrm{Mg} \mathrm{ha}^{-1}$ of WP (Tab. 2).

To have a general perspective of the effect of the soil incorporation of different amounts of WP on the fatty acids profile, and to learn more about the correlations among the fatty acids measured in the sunflower oil seeds, the analytical data were subjected to PCA.

Figure 1 shows the bi-centred projections of the scores of the examined samples and the loads of the measured fatty acids on the plane of the first two principal components displaying 
the $70.8 \%$ of total variance. In this representation, all the 48 samples were subdivided into eight distinguishable groups, each comprising the six replicate samples submitted to the treatment with the same dose of WP, and displaced from the right side to the left side of Figure 1 in the order corresponding to an increasing amount of WP used in the experimental trial.

The plot of the loadings of the measured fatty acids in Figure 1 emphasizes the individual role of the variables in separating the groups. The fatty acids C16:0, C18:0, C18: 1, C20:0, and C22:0 contributed mainly to separate the groups of samples corresponding to lower amounts of WP, while the fatty acids $\mathrm{C} 18: 2, \mathrm{C} 18: 3$ and $\mathrm{C} 20: 1$ contributed to separate the groups corresponding to higher doses of WP. This means that soil incorporation of the increasing doses of WP affected the fatty acids composition in the oil of the sunflower seeds: with respect to the control, the levels of palmitic, stearic, oleic, arachic, beehnic acids and saturated fatty acids fraction decreased; the levels of linoleic, eicosenoic, and linolenic acids increased. The levels of beehnic and lignoceric acids and the unsaturated fatty acids fraction were unaffected by the trial.

The variations of the fatty acids are quantitatively deducible from the results reported in Table 3. With respect to the control and the samples where higher doses of WP were submitted (210.0 $\mathrm{Mg} \mathrm{ha}^{-1}$ ), the percentage compositions of palmitic, stearic, oleic and arachic acids diminished by $6.3 \%, 9.5 \%, 5.4 \%$ and $22.2 \%$, respectively while it increased in the linoleic, eiocosenoic and linolenic by, respectively, 6.6\%, $23.5 \%$, and $35 \%$. The satured fatty acids fraction decreased by $7.5 \%$, the unsatured fraction remained constant, mostly because of the inner conversion of oleic into linoleic acid. This result, probably, is due to an enhancement of $\varnothing 12 \mathrm{de}$ saturase enzyme activity, which is responsible for the conversion of the oleic acid into linoleic acid. (Garcès and Mancha, 1989).

\section{Conclusions}

Little attention has been allocated in the literature to the importance of the agronomic factors on the acids' composition of sunflower yield, notably on the effect of olive waste incorporation.
The data obtained reveal that in Mediterranean environments, the application of this oil industry by-product to the soil and before sunflower seeding causes crop non-uniformity as influenced by the applied waste rates.

The soil incorporation of $35 \mathrm{Mg} \mathrm{ha}^{-1}$ of WP is well tolerable by the crop, expressed by any yield reduction as compared to the control treatment. Increasing amounts of waste (till 140 $\mathrm{Mg} \mathrm{ha}^{-1}$ ) induce an increase in the seed oil yield. Therefore, as the incorporated WP rate is higher as a result of the consequences induced by the seed yield reduction and the oil yield increase, the highest oil yield (54.7 $\left.\mathrm{g} \mathrm{plant}^{-1}\right)$ combined with a high oleic acid content was observed for the crop submitted to a spreading of $35 \mathrm{Mg} \mathrm{ha}^{-1}$.

The olive pomace has also caused a variation in fatty acids oil profile. A significant reduction in oleic acid content and a significant increase in linoleic acid amount were observed. It is important to emphasize this variations because oleic and linoleic acids represent the principal fatty acids (beyond $90 \%$ of total fatty acids content) and they affect the main nutritional and technological properties of oil. In fact, linoleic acid is considered an essential fatty acid (Holman et al., 1988), whereas a high oleic acid content encourages a high oxidative stability (Lagravère et al., 1998).

\section{References}

Amirante P. 1996. Qualità, produttività e ambiente: aspetti imprescindibili della nuova tecnologia olearia. Riv. Ing. Agr. Quad., 17:237-250.

Anastasi U., Cammarata M., Abbate V. 2000. Yield potential and oil quality of sunflower (oleic and standard) grown between autumn and summer. Ital. J. Agron., 4:23-36.

Anastasi U., Cammarata M., Sortino O., Abbate V. 2001. Comportamento agronomico e composizione lipidica degli acheni di due ibridi di girasole (convenzionale e alto oleico) in risposta a fattori ambientali. Riv. Agron., 35:76-86.

Andrich G., Fiorentini R., Galoppini G. 1986. Composizione e trattamento delle acque di vegetazione delle olive. Agric. Ital., 116:1-13.

Baldini M., Giovanardi R., Tahamasebi-Enferadi S., Vannozzi G.P. 1999. Effetti del regime idrico sulla composizione acidica dell'olio di ibridi di girasole normali e ad alto oleico. Proceedings of the XXXIII Congress of the Italian Society of Agronomy, Legnaro, Italy, 216-217. 
Baldini M., Giovanardi R., Vannozzi G.P. 2000. Effect of different water availability on fatty acid composition of the oil in standard and high oleic sunflower hybrids. In: Proceedings of XV International Sunflower Conference. Toulouse, France, 1:79-84.

Balice V., Carrieri C., Cera O. 1990. Caratteristiche analitiche delle acque di vegetazione. Rivista Italiana Sostanze Grasse, 67:9-16.

Bonari E., Ceccarini L. 1991. Spargimento delle acque di vegetazione dei frantoi sul terreno agrario. Inf. Agr., 13: 49-57

Bonari E., Ceccarini L., 1993. Sugli effetti dello spargimento delle acque di vegetazione sul terreno agrario: Risultati di una ricerca sperimentale. Genio Rurale, 5:60-67.

Bonari E., Ceccarini L. 2000. Effetti della distribuzione di dosi crescenti di sanse umide sul terreno agrario. Smaltimento e riutilizzo dei reflui dei frantoi. A.R.S.I.A. Regione Toscana, Effeemme Lito Srl, Firenze, 3:1-57.

Bonari E., Ceccarini L., Giannini C. 2001. Studio degli effetti della distribuzione dei reflui di frantoio (A.V.) in diversi terreni coltivati a soia. Proceedings of the XXXIV Congress of the Italian Society of Agronomy, 17-21 September, Pisa, Italy, 97-98.

Casa R., D'Annibale A., Pieruccetti F., Giovannozzi Sermanni G., Locascio B. 2001. Abbattimento della componente fenolica in reflui oleari: effetti sulla germinabilità del frumento duro. Proceedings of the XXXIV Congress of the Italian Society of Agronomy, 17-21 September, Pisa, Italy, 19-20.

Ceccon P., 2001. Effetti agronomici e ambientali dell'applicazione di acque di vegetazione al frumento. Proceedings of the XXXIV Congress of the Italian Society of Agronomy, 17-21 September, Pisa, Italy, 4748.

Comacho, C.B., Torres J.G., Fernandez J.L.G. 2000. Influencia de la humedad en la evolucion de parametros quimicos de un suelo tras la adicion de alperujo. Edafologia, 7, 2:215-220.

Cucci G., Rotunno T., De Caro A., Lacolla G., Di Caterina R., Tarantino E. 2004. Variation in the acid composition of sunflower (Helianthus annuus L.) seeds as influenced by soil type and irrigation water quality. $55^{\text {th }}$ IEC Meeting of the international Commission on Irrigation and Drainage (ICID), 5-11 September, Moscow, 113-125.

Cucci G., Rotunno T., Di Caterina R., Lacolla G. 2005. Relazione fra interramento di sanse umide, resa in olio e profilo acidico di semi girasole (Helianthus annuus). Proceedings of the XXXVI Congress of the Italian Society of Agronomy, 20-22 September, Foggia, Italy, 320-321.

Delpanque B. 2000. Intèret nutritionnel des tournesols. In: Proceedings of XV International Sunflower Conference, Toulouse, 1, PIB, 15-16.

European Economic Commission (RE. C), 1991. Procedure B-N-L 248/45.
Fick G.N. 1984. Inheritance of high oleic acid in the seed of sunflower Proc. $6^{\text {th }}$ Sunflower Forum. Bismarck, N. Dakota (USA).

Flagella Z., Rotunno T., Tarantino E., Di Caterina R., De Caro A. 2002. Changes in seed yield and oil fatty acid composition of high oleic sunflower ( $\mathrm{He}$ lianthus annuus L.) hybrids in relation to the sowing date and the water regime. Eur. J. Agron., 17:221-230.

Flagella Z., Giuliani M.M., Rotunno T., Di Caterina R., De Caro A. 2004. Effect of saline water on oil yield and quality of a high oleic sunflower (Helianthus annuus L.) hybrid. Eur. J. Agron., 21:267-272.

Francois L.E., Maas E.V., Donovan T.J., Young V.L. 1986. Effect of salinity on grain yield and quality, vegetative growth, and germination of semi-dwarf and durum wheat. Agron. J., 78:1053-1058.

Garcés R, Garcia J. M., Mancha M. 1989. Lipid characterization in seeds of a high oleic acid sunflower mutant. Phytochemistry, 28:2597-2600.

Gargano A., Toppino P.M. 1981. Composizione acidica e rapporti significativi del burro. La Rivista della Società Italiana di Scienza dell'Alimentazione, 1:25-30.

Grundy S.M. 1986. Comparison of monounsaturated fatty acids and carbohydrates for lowering plasma cholesterol. New Engl. J. Meid., 314:745-748.

Grundy S.M. 1989. Monounsature fatty acids and cholesterol metabolism: implications for dietary recommendations. The Journal of Nutrition, 119:529-533.

Holman RT., Johnoson SB., Hatch TF. 1988. A case of human linoleico acid deficiency involving neurological abnormalities. Am. J. Clin. Nutr., 35:617-623.

Lagravère T., Kleiber D., Daydè J. 1998. Performance agronomique et conduites culturales du tournesol oléique. Rèalitèes et perspectives. Olèagineaux Corps Gras Lipides, 5, 6:477-485.

Laureti D., Del Gatto A., Pieri S., Monatti M., Del Pino A.M. 2000. Valutazione di cultivar di girasole alto oleico nell'Italia centrale. L'Inf. Agr., 56:47-51.

Lynch J.M. 1980. Effects of organic acids on the germination of seeds and growth of seedlings. Plant, Cell. Environ, 3:255-259.

Marambe B., Ando T. 1992. Phenolic acids as potential seed germination inhibitors in animal waste composts. Soil Sci. Plant Nutr., 38:727-733.

Massart D.L., Vandeginste B.G.M., Deming S.N., Michotte Y., Kaufman L. 1988. Chemometrics: Textbook Elsevier, Amsterdam, 3:374-375.

Miller J.F., Zimmerman D.C., Vick B.A. 1987. Genetic control of high oleic acid content in sunflower oil. Crop. Sci., 27:923-926.

Monotti M., Del Pino A.M., Laureti D., Mazzoncini M., Pieri S. 1999. Valutazione di varietà di girasole coltivate in Italia nel 1998. L'Inf. Agr., 55:10-19.

Monotti M. 2002. Tecniche agronomiche per il miglioramento della produzione di olio di girasole ad alto contenuto di acido oleico. Riv. Agron., 36:69-76. 
Olivier J.D. 1993. Formation of viable but noncolture cell. In: Starvation of Bacteria. Kjelleberg S. Ed. Plenum Press. New York, 239-272.

Papini R., Pellegrini S., Vignozzi N., Pezzarossa B., Pini R., Ceccarini L., Pagliai M., Bonari E. 2000. Impatto dello spandimento di reflui oleari su alcune caratteristiche chimiche e fisiche del suolo. Atti XVIII Convegno Nazionale della Società Italiana di Chimica Agraria, 20-22 settembre, Catania, 226-234.

Paris P. 1998. Aspetti agronomici dell'impiego dei reflui dell'industria agro-alimentare. Riv. Agron., 32:196-220.

Pritoni G., Amaducci M.T., Venturi G. 1999. Accumulo di acido oleico in girasole in funzione della concimazione azotata ed epoca di semina. Proccedings of the XXXIII Congress of the Italian Society of Agronomy, Legnaro, Italy, 214-215.

Proietti P., Caterchini A., Tombesi A. 1988. Influenza delle acque di frantoi oleari su olivi in vaso e in campo. L'Inf. Agr., 44:87-91.

Rice E.L. 1979. Allelopathy. Bot. Review, 45,15.

Riffaldi R., Saviozzi A., Levi-Minzi R. 1990. Retention of coumaric acid by soil and its colloidal components. WA.S.P., 51:307-315.

Santonoceto C., Anastasi U., Riggi E., Abbate V. 1999.
Dinamica di accumulo della sostanza secca dell'olio e dei principali acidi grassi negli acheni di girasole (Helianthus annuus L.) in rapporto al genotipo ed al regime idrico. Proceedings of the XXXIII Congress of the Italian Society of Agronomy, Legnaro, 212-213.

Santonoceto C., Anastasi U., Riggi E., Abbate V. 2003. Accumulation Dynamics of Dry Matter, Oil and Major Fatty Acids in Sunflower Seeds in Relation to Genotype and Water Regime. Ital. J. Agron., 7, 1:3-14

Saviozzi A., Levi-Minzi R., Riffaldi R., Lupetti A. 1991. Effetti dello spandimento di acque di vegetazione su terreno agrario. Agrochimica, 35:135-148.

Tedeschi P., d'Andria R., Lavini A., Giorgio P., Sorrentino G., Romano G. 1997. Effetto dell'irrigazione con acqua salmastra sulla resa in granella e olio, sullo stato idrico e sulla fotosintesi fogliare di una coltura in pieno campo di girasole (Helianthus annuus L.). Irrig. Dren., 44:45-49.

Wlassics I., Burzio F., Visentin W. 1992. Per ossidasi $+\mathrm{H}_{2} 0$ : un metodo efficace ed ecologico per il trattamento delle acque di vegetazione. Riv. It. Sost. Grasse, 69:141-145.

Yodice R. 1990 Nutritional and stability characteristics of high oleic sunflower seed oil. Fett. Wiss. Technol., 92:121-126. 